\title{
How not to protect databases
}

\begin{abstract}
A battle is raging between opponents and supporters of a proposed new treaty on database protection. A period of consultation is essential so that information users can properly assess the impact of the treaty.
\end{abstract}

WITH luck, time will run out at a conference of the World Intellectual Property Organization (WIPO) in Geneva next month. Treaties on the protection of literary and artistic works, and the protection of the rights of performers and producers of phonograms, are on the agenda. But there is also a proposal to protect compilers of databases whose adoption would best be delayed .

The main purpose of the database protection treaty is to prevent anybody who invests significantly in compiling a database from having a return on that investment undermined by someone else copying the data for resale. That practice is all too easy in electronic publishing in particular. Recent court cases have highlighted situations where publishers have spent considerable sums in producing directories, only to find that they cannot protect the product against being copied for profit by others because of the lack of creativity involved in its compilation.

There is, admittedly, more than a whiff of protectionism in the air. In the United States, the information industry is acutely concerned about the effects of a European Directive already adopted in March this year, designed to address this issue but in a way that, some claim, is prejudicial to database suppliers outside Europe. That directive is being implemented in the 15 member states of the European Union and 15 other European countries. US publishers are keen, understandably, to level the playing-field, but are vigorously supporting a treaty proposal that scientists and other database users regard as potentially dangerous and unacceptable.

The word 'database' in the treaty applies to any collection of information that is searchable. As a result, climate data, gene sequences and other scientific data would be included. Frequently, such data have been gathered using public funds. On the face of it, the treaty, and a similar, equally controversial bill before the US Congress, would allow such data to be extracted and sold by a commercial organization which might add little value, yet turn a public good to private gain. Also, the period of protection (15 years is the shortest proposed) could be renewed simply by updating the database. Those possibilities are not in themselves undesirable, but their potential implications for some users appear to be.

What, in particular, of scientists wishing to use the data? There is no mention in the treaty of exemptions for educational and research use, as applies in copyright legislation. True, the WIPO draft treaty would allow the nations that implement it to legislate for exceptions. But the burden of opposition then falls on those traditionally protected (in Anglo-Saxon countries at least) by 'fair use' exemptions from copyright payments, who will to have to fight their case in every country. And that against an economic background in which the commercial suppliers themselves, threatened by the communicative promiscuity of digital storage and communication, perceive a need to capture every advantage that they can simply to protect themselves.

Predictions of the effect of the treaty on costs are controversial. Librarians and academics see it as handing a licence to print new money at their expense to commercial suppliers of databases based on government data. The database supplier and the government agency save costs and gain revenue, whereas the public loses a public good and could well be confronted by a monopoly.

One of the few voices endorsing the WIPO treaty is the US Information Industry Association, which represents 550 informa- tion companies. It claims that the lack of a WIPO treaty undermines its members' confidence in the market and stops them investing, thus reducing choice and quality to US database users. But this glosses too readily over the concerns of what is, after all, an important part of the industry's customer base. In the United States, scientists and other database users have not been adequately consulted. But their worries are justified and more comprehensive debate is needed. That is why discussion of the database protection treaty should be removed from WIPO's December agenda.

\section{Russian roulette}

The fate of Russian science has recently turned from drama to tragedy. Imaginative help from the West is much needed.

GRAND designs to sustain the intellectual vitality of science in the countries of the former Soviet Union have given way to a narrower effort supporting only those parts of the enterprise that Western governments are really concerned about - the science behind Russian weapons of mass destruction. The West's greatest fear is that plutonium or highly enriched uranium could leak to any state, terrorist group or criminal gang. Leaked skills and knowledge are a less direct - if equally potent - concern.

Until recently, the main Russian nuclear weapons laboratories had been sheltered from the disruption that has crippled many other Russian research institutes over the past four years. The weapons laboratories have retained most of their staff, living and working inside large and remote closed cities, far from the distractions which have emptied the corridors of research laboratories in Moscow. This year, however, staff at the laboratories have gone unpaid for months. The recent suicide of Vladimir Nechai, director of Chelyabinsk-70, has underlined the plight of the laboratories.

Western aid for civil science has all but dried up. But Western aid - as well as the military priorities of the Russian government - continues to buttress the weapons laboratories against collapse. The International Science and Technology Center (ISTC) in Moscow, established two years ago by the United States, the European Union and Japan to fund civilian projects proposed by Russian weapons scientists, has properly concentrated on getting grant money straight into researchers' hands. This allows a little money to go a long way. The $\$ 12$ million spent on projects at Arzamas, for example, will partially or fully supports 1,200 recipients there for several years. Other US endeavours costing far more - such as the \$1.5-billion Co-operative Threat Reduction programme - are subject to various restrictions to ensure that most of the 'aid' is not actually spent in Russia or its neighbours.

The ISTC is one example of how relatively smaller sums, used as essentially a life support system for Russian scientists, can be equally effective. The financier George Soros realized the important of this approach in setting up his International Science Foundation. It has also been mirrored by the European aid programme, INTAS. If more funds could be spent in this way, perhaps Russian science could find a way of its tragic situation. 